\title{
PATRIMONIALISMO, TECNOBUROCRACIA E NEOLIBERALISMO: A REFORMA DO ESTADO NO GOVERNO JAIME LERNER (1995-2002) ${ }^{1}$
}

Walter Luiz Mauch ${ }^{2}$

- Enviado em 16/01/2016

- Aprovado em 21/02/2016

Nossa proposta de dissertação tem por objetivo analisar a fusão entre o discurso e prática liberal com as formas e métodos tradicionais - patrimonialismo, personalismo, individualismo e nepotismo - dos agentes sociais na administração pública do Estado do Paraná nos governos Jaime Lerner (1995-2002).

Nos dois mandatos de governador do Paraná, Jaime Lerner introduziu modificações na forma pela qual o Estado interage no âmbito social e econômico. Foram criadas as organizações sociais autônomas, que deveriam assumir funções e prerrogativas antes exclusivas do poder público, e desmanchou-se o sistema estadual de planejamento econômico. Mudanças calcadas no ideário liberal, baseadas na modernização e redução do aparelho do Estado, colidiram com pesada herança colonial do amálgama entre público e privado, perpetuando práticas patrimonialistas na condução do Estado brasileiro. Desta forma, visamos compreender como se desenvolveu e que feição tomou o projeto paranista de modernização conservadora instituído no governo Lerner, frente às necessidades da elite política em manter as relações tradicionais de dominação. Partiremos da trajetória política e profissional do governador Lerner, estreitamente ligada à criação, durante o regime militar, de uma tecnoburocracia no Instituto de Pesquisa e Planejamento Urbano de Curitiba (IPPUC). Analisaremos como as decisões e atos da administração estadual foram implantados de

\footnotetext{
${ }^{1}$ Pesquisa de mestrado em andamento sob a orientação do Professor Doutor Ricardo Costa de Oliveira no Programa de Pós-graduação em Sociologia da UFPR.

${ }^{2}$ Graduado em Ciências Econômicas pela UFPR. Endereço eletrônico: walterluiz.mauch@ gmail.com
} 
forma a conciliar a necessidade de modernização liberal com as demandas e práticas políticas dos diversos grupos e famílias que detêm o poder na sociedade paranaense.

Desde a primeira eleição presidencial pós-regime militar, em 1989, o eixo central do debate político que divide campos adversários é sobre o papel e o tamanho do Estado no Brasil. No campo liberal a fundamentação ideológica e o programa político podem ser sintetizados nos seguintes pontos: crítica ao modo burocrático de gestão pública, redução das funções do Estado via mecanismos de mercado, implantação de uma cultura gerencial através de resultados e a descentralização administrativa. No Paraná, o programa liberal foi o esteio programático das duas gestões do governador Jaime Lerner (1995-2002) e teve continuidade na atual administração Beto Richa. Desta forma, o eixo do debate, a capacidade do Estado como gestor, indutor do desenvolvimento e prestador de serviços continua em foco e polariza os campos políticos adversários em todos os níveis da administração pública brasileira. Estudos e pesquisas sobre o processo de amálgama do projeto liberal de modernização com o tradicionalismo das elites políticas brasileiras, calcadas na gestão patrimonialista e tecnoburocrática do Estado, fornecem uma radiografia do modus operandi desta fração da classe dominante e permitem reflexionarmos sobre as peculiaridades e dificuldades da gestão estatal e democratização do Estado no Brasil.

Baseado em um discurso de eficácia e eficiência gerencial, influenciados pelos governos Thatcher e Reagan, a reforma da administração e planejamento do Estado, implementada nos dois mandatados do governador Jaime Lerner, adquiriu peculiaridades que destoam dos ideais apontados pelo modelo dos países matriz. Já característico da nossa história, a adequação aos processos econômicos e sociais dos países hegemônicos assume a feição de dependência heteronômica (a introjeção de valores e razões exógenos), amalgamando distintas fases e momentos em um só processo histórico. Assim, o tecnoburocrata, produto das fases maduras do desenvolvimento capitalista, não rompe com os fundamentos históricos do processo de apropriação do Estado pelas classes e extratos dominantes. O patrimonialismo, o personalismo e a centralização administrativa se combinam com os fundamentos do liberalismo econômico, moldando uma configuração de Estado e administração pública que nos é própria e já distinta do modelo matriz.

Nosso trabalho irá contemplar duas fases, sendo a primeira uma revisão de literatura que forneça fundamentação teórica sobre o tema, nos aspectos econômicos, históricos e políticos. $\mathrm{Na}$ segunda parte, focada diretamente no assunto, iremos reunir material bibliográfico - documentos, entrevistas, projetos de lei, relatórios de Comissão Parlamentar de Inquérito - sobre os atos e fatos do governo Lerner que conformaram o projeto neoliberal paranista. 